\title{
The Awareness of High School Teachers on their Instructional Leadership Roles ${ }^{1}$
}

\begin{abstract}
Ulku Tosun*
Bilal Aygun**

*Assistant Professor, Fatih University, Turkey; e-mail: ulku.tosun@fatih.edu.tr ${ }^{* *}$ Education Management Specialist, Turkey; e-mail: baygun@hotmail.com

\section{Doi:10.5901/jesr.2014.v4n2p215}

Abstract

The aim of this study is to examine the level of high school teachers' awareness on instructional leadership roles according to their perceptions. The sample of this study was composed of high school teachersin Beylikduzu and Buyukcekmece districts in Istanbul. The participants were administered by 'Demographic Questionnaire' and 'The Instructional Leadership Roles of Teachers' questionnaire developed by the researcher. The data were analyzed by SPSS 20 program. The questionnaire were converted to a scale by verifying reliability and validity statistics. The results includes the frequencies, the percentages and the means of the teachers' awareness on instructional leadership roles. The variations of teachers' awareness on instructional leadership roles according to demographic variables were tested by independent samples t-test and ANOVA. The results shows that high school teachers' awareness on instructional leadership roles were high level in all sub dimensions.
\end{abstract}

KeyWords: Leadership, Teacher Leadership, Instructional Leadership Roles

\section{Introduction}

Leadership, which has appeared as a result of societies's need of people who will drag them in a certain direction, has gained more importance nowadays and it is being mentioned in all areas. As education is an important factor of changes and coping with the problems that arise in these cases, it has been inevitable that teachers exhibit leadership manners in this changing and constantly renewed social life (Can, 2007, p. 164-165). Teachers should be leaders who are enterprising, can renew and manage themselves, capable of taking decisions, internalize and comment on educational values and who are able to undertake the responsibility of this. As a matter of fact that the teacher has such characteristics of creativity, directivity, effectiveness, leadership and so on will carry today's students into the knowledgebased society of the future (Bostancl, 2011, p. 216).

\subsection{Instructional Leadership}

Instructional leadership is the competency of being able to plan and organize educational and instructional activities effectively and undertake active roles and develop them by performing leadership in the learning process and developing and sharing an educational vision. The main purpose of instructional leadership is the arrangement of the school environment as one which is productive and completely towards instruction (Erdoğan, 2004, p. 88). Teacher leadership is the skills and qualifications the teachers of the future should have (Urbanski and Nickolaou, 1997, p. 248; Hoyt, Price and Emrick, 2010, p. 404; Johnson and Snyder, 1986). A leader teacher is one who is perfect in his or her class, continuously learn as a student does, can also exhibit talent and performance outside the school, is involved at the center of changes to raise the quality of education and who posesses leadership skills. The main objective of the teacher leadership is to improve the quality of education (Hook, 2006, p. 13).

\subsection{Teacher Leadership Roles}

As a result of studies in the regarding literature, the teacher's instructional leadership roles are specified in the following

1 This study has been constructed from the master degree thesis titled "A Study On High School Teachers For Their Instructional Leadership Roles And Their Approaches Toward The Restricting Factors Of Instructional Leadership" written by Bilal Aygun. 
ways (Bostancı, 2011; Can, 2006; Gökyer, 2004; Gümüşeli, 1996; Sümbül, 1996; Şişman, 2004) :

1. Defining, announcing and sharing the vision and mission of the school

2. Planning, implementing, supervising and evaluating the instruction

3. Creating a positive teaching-learning climate and classroom culture

4. Monitoring and rewarding students' development and success

5. Individual transformation and professional development of teachers

6. Supporting the development of other teachers and being a model

7. Adapting to environmental and social values

8. Providing support of the environment and society

\subsection{Problem}

What is the high school teachers' awareness of instructional leadership roles and and the level of realizing such roles?

\subsection{Purpose}

The purpose of this study is to determine at which level do high school teachers in a certain environment perform instructional leadership roles.

\subsection{Importance of the Research}

Because of the adolescent characteristics, it is more suitable to conduct the research in high schools. As high school teachers perform leadership and are a role model for high school students, it is regarded as important that they be aware of instructional leadership roles and exhibit such roles.

It is expected that the research will contribute to any programs to be organized in terms of training and improving teachers through in-service training sessions and training qualified leader teachers.

\section{Methods}

\subsection{Research Model}

As this research is descriptive in nature, the survey model was used. Survey models are the research 84 approaches aiming to describe an existing situation in the past or present situation as it is (İslamoğlu, 2009, p. 85).

\subsection{Procedure}

415 teachers constitute the sample group who are chosen as conformity sampling among the teachers working in public and private high schools in Beylikdüzü and Büyükçekmece districts of the city of İstanbul, Turkey. Research findings have been collected by using a 5 point Likert-type questionnaire and a demographic variables form. After applying the factor analysis and validity and reliability studies, the questionnaire was turned into a scale named " Teachers' Instructional Leadership Roles " and the relevant assessments were made on this scale. In the factor analysis of variables related to instructional leadership roles, a strong factor structure is obtained, the obtained factor loadings explain $61.4 \%$ of the total variance in all the variables. The fact that factor loadings are high indicates that questions share a common variance with other questions (İslamoğlu,2009). It was found out that the KMO value is 0.895 and Cronbach's coefficient alpha is 0.909 . In the analysis of the collected data SPSS 20 software package was used. 


\section{Conclusion}

Table 1: Demographic Variables

\begin{tabular}{|c|c|c|c|}
\hline \multicolumn{2}{|c|}{ Demographic Variables } & $\begin{array}{c}\text { Frequency } \\
\text { (N:415) }\end{array}$ & $\begin{array}{c}\text { Percent } \\
\text { (\%) }\end{array}$ \\
\hline \multirow{4}{*}{ Gender } & Male & 203 & $\% 48,9$ \\
\cline { 2 - 4 } & Female & 212 & $\% 51,1$ \\
\hline \multirow{4}{*}{ Graduation Degree } & Associate degree & 4 & $\% 1,0$ \\
\cline { 2 - 4 } & Banchelor & 319 & $\% 76,9$ \\
\cline { 2 - 4 } & Master & 87 & $\% 21,0$ \\
\cline { 2 - 4 } & Doctorate & 5 & $\% 1,2$ \\
\hline \multirow{4}{*}{ School Type } & General high school & 30 & $\% 7,2$ \\
\cline { 2 - 4 } & Anatolian high school & 150 & $\% 36,1$ \\
\cline { 2 - 4 } & Science high school & 20 & $\% 4,8$ \\
\cline { 2 - 4 } & Private high school & 86 & $\% 20,7$ \\
\cline { 2 - 4 } & Religious high school & 30 & $\% 7,2$ \\
\cline { 2 - 4 } & Vocational high & 99 & $\% 23,9$ \\
\hline \multirow{4}{*}{$\begin{array}{c}\text { school } \\
\text { Erofessional }\end{array}$} & $1-5$ years & 72 & $\% 17,3$ \\
\cline { 2 - 4 } & $6-10$ years & 73 & $\% 17,6$ \\
\cline { 2 - 4 } & $11-15$ years & 118 & $\% 28,4$ \\
\cline { 2 - 4 } & $16-20$ years & 83 & $\% 20,0$ \\
\cline { 2 - 4 } & $21-25$ years & 43 & $\% 10,4$ \\
\cline { 2 - 4 } & 26 and more & 26 & $\% 6,3$ \\
\hline Total & & 415 & $\% 100$ \\
\hline
\end{tabular}

Table 2: Teachers' Level of Implemeting Instructional Leadership Roles

\begin{tabular}{|c|l|c|c|c|}
\hline \multicolumn{1}{|c|}{ Instructional Leadership Roles of Teachers } & Average $(\bar{X})$ & $\begin{array}{c}\text { Standard } \\
\text { Deviation (SD) }\end{array}$ & $\begin{array}{c}\text { Implemented } \\
\text { Level }\end{array}$ \\
\hline $\mathbf{1}$ & Defining, announcing and sharing the School Vision and Mission Statement & 3,87 & 0,91 & High \\
\hline $\mathbf{2}$ & Planning, implementing, supervising and evaluating the instruction & 4,23 & 0,76 & Very High \\
\hline $\mathbf{3}$ & Creating a positive teaching-learning climate and classroom culture & 4,41 & 0,65 & Very High \\
\hline $\mathbf{4}$ & Monitoring and rewarding students' development and success & 4,2 & 0,8 & Very High \\
\hline $\mathbf{5}$ & Individual change and professional development of teachers & 4,11 & 0,81 & High \\
\hline $\mathbf{6}$ & Supporting the development of other teachers and being a model & 4,21 & 0,84 & Very High \\
\hline $\mathbf{7}$ & Adapting to environmental and social values & 4,31 & 0,73 & Very High \\
\hline $\mathbf{8}$ & Providing support of the environment and society & 2,49 & 1,26 & Low \\
\hline & Average & $\mathbf{3 , 9 8}$ & $\mathbf{0 , 8 4 5}$ & Very High \\
\hline
\end{tabular}

That teachers have higher awareness sizes in instructional leadership roles is consistent with the results of other research (Akbaşlı, 2011, p.75-90; Bostancı,2011; Armstrong,2013; Sümbül,1996, p.605; Şişman,2011, p.160).

When teachers' instructional leadership roles are evaluated in terms of demographic variables, in terms of "Gender" a significant difference was not observed. This may be interpreted in such a way that female and male teachers do not evaluate the issue of instructional leadership not on the basis of gender but on the basis of their professions. On the other hand, regarding the dimension of 'individual transformation and professional development of teachers', with the perceptions of male and female teachers, there were significant differences in favor of male teachers. It can be considered that this difference is associated with the negative impact of women's responsibilities at home on their professional progress .

When teachers are evaluated according to their " Graduation Degrees ", it has been found that they are aware of their instructional leadership roles and they perform the manners of these roles at high levels. In this study, it has been seen that five teachers who have the doctoral degrees appear to have a higher awareness, unlike the other teachers, in planning and implementation of education and instruction in the classroom and being compatible with the environment and society and taking support of the social environment.

That teachers who are engaged in academic study in their own fields and who did master's and doctorate studies 
have increased leadership skills and high awareness is also supported by a lot of researches in the literature.

When the evaluation of teachers is examined in terms of "Professional Experience", regarding the dimension of "Defining, announcing and sharing the vision and mission of the school" it is seen that teachers with 1-5 years of experience and teachers with 26 years and above experience have high level of awareness, whereas the rest groups have a medium level of awareness. The reason for the level differences can be considered to derive from the fact that in the early years of work teachers are dynamic and sensitive in making the requirements of teaching and from the self confidence which 26 years of professional experience has brought. Especially, thinking that this dimension is mostly the roles of principals may be another cause.

When teachers' evaluations are analyzed according to "School Type", it is observed that they are aware of their instructional leadership roles and perform the manners of these roles at a high level, but the dimension of "Monitoring and rewarding students' development and success " at a low level. Teachers' having classes more than enough and their formal class schedules' occupying all their time create time constraints, and the excess number of students in classes is a barrier to perform the role of monitoring and rewarding students' development and success (Ozdemir ve Yalın, 2000, p.185). When the school types and the size of the scale are compared separately by the ANOVA test, it is observed that Anatolian high school teachers exhibit significantly different manners from teachers in other institutions in one dimension (Professional transformation and development of teachers); private school teachers in two separate dimensions of ("Creating a positive teaching-learning climate and classroom culture" and "Providing support of the environment and society"), and the teachers of religious high school in the rest four different dimensions. This situation may be associated with differences in corporate structure and functioning of public and private high schools. It can be said that at private schools, school structure and functioning is more flexible and more focused on organizational development and effectiveness. These findings are consistent with the results of Beycioğlu and Aslan (2010) study. However, there is not enough work with the field literature regarding the religious high school teachers who make a positive difference in this study.

\section{Implications}

It can be suggested that teachers having high levels of awareness in eight different dimensions of leader teachersip can be given the status of leader teacher and take an active role in major projects related to education in education units ( Ministry, provincial, district and regional education directorates).

It can also be suggested that school administrators involve teachers in the decision-making process of defining the vision and mission of the school, identifying, sharing, developing and applying the aims of the school in an active.

When editing in-service training, Ministry of Education and local organizations can prepare programs which can develop instructional leadership by taking into account the needs of teachers and education and the the conclusions and implications of scientific research.

\section{References}

Beycioğlu, K., \& Aslan, M. (2010). Okul Gelişiminde Temel Dinamik Olarak Değişim Ve Yenileşme: Okul Yöneticileri Ve Öğretmenlerin Rolleri. Yüzüncü Yıl Üniversitesi, Eğitim Fakültesi Dergisi , 7 (1), 153-173

Bostancı, A. B. (2011). Sınıfta Illişki Düzenini Oluşturmada Öğretmenin Liderliği. C. Gülşen içinde, Kuram Ve Uygulamada Sınıf Yönetimi (s. 215239). Ankara: Anı Yayıncılık.

Can, N. (2006). Öğretmen Liderliğinin Geliş̧ririlmesinde Müdürün Rol Ve Stratejleri. Sosyal Bilimler Enstitüsü Dergisi (21), 349-363.

Can, N. (2007). Sınıfta Bir Lider Olarak Öğretmen. M. Şişman, \& S. Turan içinde, Sınıf Yönetimi (s. 161-174). Ankara: Pegem A Yayıncılık.

Çelik, V. (2007). Eğitimsel Liderlik. Ankara: Pegem A Yayıncııı.

Erdoğan, İ. (2004). Okul Yönetimi Öğretim Liderliği. İstanbul: Sistem Yayıncılık.

Gökyer, N. (2004). Illköğretim Okulu Müdürlerinin Öğretim Liderliği Rollerini Gerçekleştirme Düzeyleri ve Bu Rolleri Sınırlayan Etkenler( Yayınlanmamış Doktora Tezi). Ankara: Hacettepe Ünv.Sosyal Bilimler Enstitüsü.

Gülşen, C., \& Gökyer, N. (2012). Türk Eğitim Sistemi ve Okul Yönetimi. Ankara: Anı Yayıncılık.

Gümüşeli, A. İ. (1996). İstanbul İli İlköğretim Okulu Müdürlerinin Öğretim Liderliği Davranışları.Yayınlanmamış Araşsırma. İstanbul: Yıldız Teknik Üniversitesi Fen Edebiyat Fakültesi.

Hoyt, C. L., Price, T. L., \& Emrick, A. E. (2010). Leadership and the more important- than-average effect:Overestimation of group goals and the justification of unethical behavior. Leadership. http://lea.sagepub.com/content/6/4/391 (6), 391-407.

İslamoğlu, A. H. (2009). Sosyal Bilimlerde Araştırma Yöntemleri. İstanbul: Beta Yayıncılık.

Ozdemir, S., \& Yalın, H. İ. (2000). Öğretmenlik Mesleğine Giriş. Ankara: Nobel Yayınları.

Sümbül, A. M. (1996). Öğretmen Niteliği Ve Öğretimdeki Rolleri. Kuram ve Uygulamada Eğitim Yönetimi Dergisi (8), 597-607.

Şişman, M. (2004). Öğretim Liderliği. Ankara: Pegem A Yayıncılık.

Urbanski, A., \& Nickolaou, M. B. (1997). Reflections on teachers as leaders. Educational Policy 11(2): 243-254 , 11 (2), $243-254$. 